\title{
COMMUNICATION PERFORMANCE AND ENTREPRENEURIAL BEHAVIOR IN VILLAGE-OWNED ENTERPRISE IN MANAGING VILLAGE ENTERPRISE: A CASE STUDY OF PANGGUNGHARJO VILLAGE OF BANTUL CITY, INDONESIA
}

\author{
Kusuma S. * \\ School of Communication, Atma Jaya Catholic University, Jakarta, Indonesia \\ Hubeis A.V.S., Sarwoprasodjo S., Ginting B. \\ Department of Communication and Community Development Sciences, \\ Bogor Agricultural University, Bogor, West Java, Indonesia \\ *E-mail: satria.uaj@gmail.com
}

\begin{abstract}
BUMDes of Desa Panggungharjo (Village-owned enterprise of Panggungharjo Village) has rubbish processing, swadesa (a village-owned department store), tamanu oil processing, and village tourism business units. This research aimed to analyze the communication performance in organizational culture constructed communicatively through organizational practices in BUMDes in managing innovation, management, and strategy of BUMDes Desa Panggungharjo to be a sustainable village enterprise. This study employed qualitative method with constructivist paradigm. Techniques of collecting data used were observation, Focus Group Discussion (FGD) and interview. The result of research showed that members of BUMDes Desa Panggungharjo have communication performance in managing the village enterprise to grow the employees' loyalty and sense of belonging, to provide policy direction, participative planning, discussion and socialization, and to explore innovation, business development, and promotion.
\end{abstract}

\section{KEY WORDS}

BUMDes, communication performance, organizational culture, rural entrepreneurship, sustainable village enterprise.

Rural enterprise is the form of activity involving local element and grows at village level in many work field like business, industry, and agriculture, and serving as a strong factor to economic development (Das 2014). Village enterprise creates a large-scale job opportunity to rural people (Kushalakshi and Raghurama 2014). The growth of village enterprise can reduce such social problems as poverty, slump area growth, and pollution in urban areas and improve the village youth's consciousness of potential job in rural area and support between entrepreneurs (Das 2014; Deshwal 2015; Kashani 2015).

Village-owned enterprise (Indonesian: Badan Usaha Milik Desa, thereafter called BUMDes) is a village enterprise founded by village according to its need and potency. A year after the publication of Law No.6 of 2014 about Village and after the Ministry of Village and PDTT published Minister of Village's Regulation No.4 of 2015 about Establishment, Administration and Management, and Dismissal of Village-Owned Enterprise, Panggungharjo Village Government of Sewon Sub District of Bantul Regency adapted both regulations by publishing Village Regulation Number 9 of 2015 about BUMDes. BUMDes Panggung Lestari's bylaw, as explained in Village Regulation, mentions that the establishment BUMDes Panggung Lestari establishment is intended: 1) to improve the use value of village asset and potency as much as possible for villager welfare; and 2) to improve Panggungharjo Village Government's financial ability in organizing government and to improve the people's income through a variety of community economic activity.

Meanwhile, the objectives of BUMDes Panggung Lestari establishment are: 1) to realize rural community's independent economic institution to fulfill the people's need; 2) to support local investment activity, to explore local potency, and to improve the rural-and-urban 
economic linkage by building rural economic infrastructure needed to develop rural business' productivity; 3) to encourage the villagers' economic development by improving their capacity in planning and managing rural economic development; 4) to improve creativity and productive economic business change of villagers with low income; 5 ) to create the business opportunity and job opportunity; and 6) to increase village original income.

Village enterprise is a topic getting much attention from public agenda, due to its ability of providing and encouraging the sustainable job opportunity in rural areas (Feher, 2015). Majority village enterprises encounter some problems due to inadequate basic facilities in rural area, inadequate education, financial problem, marketing constraint, management and human resource problem, and inadequate technical and conceptual abilities (Venkateswarlu \& Ravindra, 2015). Human resource management is required in village enterprise to reinforce individuals in making decision, interacting to solve problem, and developing enterprise. It is important to prioritize knowledge, learning and skill development (Yadav \& Goyal, 2015, Hazarika, 2016) constituting the human resource element (Singh and Bhowmick, 2015), consisting of a factor necessary to entrepreneurship development (Taghibeygi et al. 2015) and innovation in rural context, in the sense of improving economic efficiency, economic scale, and economic coverage (Singh and Bhowmick, 2015).

Human resource less familiar with work relation, weakness in decision making, and less experience with entrepreneurship are personal constraints to entrepreneurship development (Kashani et al. 2015). Guta et al.'s (2017) study revealed among producers and farmers, there is no connectivity between group members in entrepreneurship and there is no reciprocity leading to low trust between members in the same business. Venkateswarlu \& Ravindra's (2015) study found poor cooperation, coordination, consultation, and work in a variety of entrepreneurship-related institutions, inadequate training, skill, and competency as serious problems in rural enterprise (Munyanyiwa \& Mutsau, 2015).

Rural enterprise can fill in the wide gap and difference between rural and urban people's incomes (Das, 2014). It can help reducing migration of people from rural to urban areas to seek job (Munyanyiwa and Mutsau, 2015). Poverty is the cause of such problems as criminality, child malnutrition, low education and poor housing facility. The growth of rural enterprise will help reduce the unemployment problem that in turn will help minimize poverty problem and other issues related to poverty (Deshwal, 2015; Kushalakshi and Raghurama, 2014).

Business performers in rural area tend to participate poorly in the attempt of utilizing local resource and to involve local people inadequately in their business (Korsgaard and Müller, 2015). Agunggunanto et al.'s (2016) revealed that the socialization needs to be conducted to the people to make them knowing the importance of participation in BUMDes program. Skill training/education and training should be held for the administrators concerning BUMDes management to improve the institutional performance. Safitri et al.'s (2016) study found that the management of BUMDes has not run maximally yet, viewed from management, performance, and leadership. Purnamasari's (2016) study found that BUMDes should develop dialog with the people. The sustainability of BUMDes is highly dependent on the ability of managing organization. Anggraeni's (2016) study found that the administrators' poor knowledge on BUMDes management and institutional performance, poor communication and socialization generate the demand for transparency and accountability of BUMDes management.

Dewi \& Meirinawati (2013) revealed that Village Regulation about BUMDes establishment mentions BUMDes management mechanism. Hayyuna, Pratiwi, and Mindarti's (2014) study found some inhibiting factor in the asset management strategy taken by BUMDes: difficulty in developing new business and limited innovation in developing local product and marketing facilities such as website to introduce service product in BUMDes. Administrators' knowledge and skill insight into management, and institutional performance in establishing and developing BUMDes business group are still low and less optimal (Ihsan 2018, Fatimah 2018). Close relationship between village government and BUMDes, dialog with people and sense of belonging are still low (Budiono 2015, Kusuma \& Purnamasari 2016, Firdaus 2018, Murwadji et al. 2017). The development of village enterprise is inhibited 
with poor managerial skill, poor understanding on management and work planning, skill, and organizational performance, and entrepreneurial skill (Taghibeygi 2015, Munyanyiwa \& Mutsau 2015). This research aims to analyze communication performance in organizational culture constructed communicatively through practices in BUMDES organization in managing innovation, management and BUMDes Desa Panggungharjo to be a sustainable village enterprise.

Organizational culture theory, according to Pacanowsky and O'Donnell Trujillo (1982), explains that members of organization conduct a certain communication performance leading to rise of unique organizational culture. Communication performance or ritual performance involves personal ritual including any thing conducted routinely in workplace. Task ritual is routine behavior related to an individual's job. Task ritual help complete the job. Social ritual is verbal and non-verbal routines usually considering the interaction with others. Social ritual can also involve nonverbal behavior. Organizational ritual is a company's activity often conducted such as leader meeting and division meeting.

Ritual, according to Littlejohn and Foss (2017), is something repeated regularly. This ritual is not strange and has been a habit like staff meeting or corporate recreation. Ritual is very important because it keeps reforming our understanding on our general experience, and legitimates what we think, feel, and do. Another task ritual (task ritual), constituting the repeated activities helping the members do their job. Social ritual is not related to the task but an important appearance in organization. Organizational ritual is the one involving work group in several regularities.

Drucker (1998) in Gani (2014) recommends three behavioral elements to be owned in order to support the successful entrepreneurship practice: purposeful innovation, enterprise management, and enterprise strategy. To make innovation, we should consider the changes occurring in our surrounding systematically. It pertains to sensitivity and diagnostic skill, two types of ability that can be learnt through practice. Entrepreneurship should find out its basic focus, to be analyzed then based on financial need anticipation. From the result of analysis existing, entrepreneur should prepare and organize peak management team and determine the role of management founder in its relation to others.

\section{METHODS OF RESEARCH}

This research used qualitative method with constructivist paradigm. Constructivist paradigm, according to Gergen Denzin and Lincoln (2017), explains the process of establishing meaning and explaining how the meaning is contained in language and action of social actor. Social constructionism builds on a view that knowledge is one of many coordinated activities conducted by individuals, and therefore is colored with the processes that also color every human interaction (i.e. communication, negotiation, conflict, rhetoric). Qualitative research, according to Neuman (2014), is collected by documenting many real events, routine activities of BUMDes members at workplace, recording anything actually said by people (with words, body movement, and tone) in the form of field observation in Panggungharjo Village where BUMDes is located, observing certain behavior in the form of routine task in BUMDes organization, checking, and learning visual image.

Techniques of collecting data used were Focus Group Discussion (FGD) with 20 informants and interview with 20 informants in Panggungharjo Village of Sewon Sub District of Bantul Regency of Daerah Istimewa Yogyakarta (Yogyakarta Special Region) Province getting reward for the best village at national level from Ministry of Interior in 2014, Ministry of Village and Left-Behind Region Development and Transmigration, Clean, transparent, and free-of-corruption village government bureaucracy model from KPK (Corruption Eradication Commission) in 2014, and MOU with BPKP about innovation of village government accountability and transparency. This research was conducted from August to November 2018. Informant consisted of key informant (the one giving important information, having knowledge and idea, understanding what is occurring, and having experience with the early establishment of BUMDes until it survives today, organizational culture, entrepreneurial behavior, and local wisdom in BUMDes Desa Panggungharjo) consisting of BUMDes Advisor 
(Head Village/Lurah of Panggungharjo), BUMDes Supervisor (Village Representative Council or BPD), Director of BUMDes, Manager of Business Unit and supporting informant constituting the employees at management level, heads of business units, SMEs administrators, FWP, Rubbish bank, and Village Cooperatives. Data processing and analyzing methods, according to Creswell (2014), were conducted by reading entire data resulting from FGD and interview with administrator, village government, and work partner, analyzing in more detailed by coding the data based on organizational culture and entrepreneurial theories, applying coding process to describe setting, people, categories, and themes to be analyzed, showing how this description and theme will be redisplayed in narrative, and interpreting data.

\section{RESULTS AND DISCUSSION}

The Performance of Panggungharjo Village Head's Ritual in managing BUMDes. Communication performance occurring regularly and repeatedly is called ritual performance consisting of personal, task, social, and organizational rituals (Pacanowsky and O'Donnell Trujillo in West and Turner 2013). The performance of Panggungharjo Village Head's ritual as the BUMDes advisor generally gives direction of policy related to BUMDes management and briefing in management, supervisor, and advisor meeting. The adjacent residences of employees make the briefing conveyed informally so that the communication runs more intensively. The objective of Village Head's communication is to ensure whether or not what BUMDes does has been on the expected corridor according to the public policy and the true path. Village Head's communication style is dependent on the substance, when it should be conducted by BUMDes administrators, it will be top-down in nature like the establishment of business management and unit; meanwhile in relation to non-substantive matter, it will give the employees the discretion to create the strategy of developing business unit.

Village Head (Lurah) establishes relation with villagers, people and friends from outside village playing in Kampoeng Mataraman. Lurah initiates the establishment of BUMDes and administrators of BUMDes communicate intensely with the Lurah who does not always ask to be too respected or afraid of, so that their communication is solid and very opened, while many BUMDes outside the village does not run synergistically with village government. It is also conducted by village government and BUMDes in Bojonegoro that involve the people's active participation openly in improving the production of BUMDes (Budiono, 2015).

Administrators of BUMDes often convey informally to the employees that the heart or the basic value of BUMDes is to build village independency and to present service to villagers. In the attempt of realizing the basic value, BUMDes establishes minimum standard of BUMDes management. Leadership, managerial affair, and management are required to make BUMDes healthy, solid, and sustainable (Eko 2014).

BUMDes organizational culture approach is performed more widely culturally and personally such as building role model, giving example directly, and holding discussion personally. Socialization meeting is held by BUMDes by means of visiting the people directly through both RT (neighborhood association) and rubbish bank existing in BUMDes downline. Information on BUMDes activity, policy, guest visit, and meeting are delivered more widely through social media and relevant meeting with RT chief and village institution. It is confirmed with Das' (2014) study finding that entrepreneurs rely on internal relationship encouraging product, service, information, and idea flows. BUMDes develops a systematic platform for financial transparency and informs the financial management by sharing address, password, user to villagers making BUMDes Desa Panggungharjo the success stories model from Corruption Eradication Commission (KPK) in the attempt of supporting a clean and transparent village government democracy.

Performance of BUMDes Panggungharjo Director's Ritual in Managing BUMDes. Director of BUMDes does any uncompleted job every morning, coordinates and sometimes asks individual unit heads and managers about the solution to internal problem of business unit management concerning the additional discount policy to the guest. Director of BUMDes opens the participation space for the employees to run BUMDes due to limited knowledge 
and ability. The standard rule of BUMDes in Kampoeng Mataraman business unit has not been enacted maximally. Meanwhile the written rule is newly enacted as the Standard Operating Procedure (SOP) and to meet the demand for a company's management.

Director of BUMDes gives briefing to business unit, convenes all employees and emphasizes that BUMDes belongs to all of them, emphasizes on the employees' loyalty to achieve the work target, holds management gathering to establish intimacy between employees and refreshing once in 3-4 months during slightly saturated circumstance of employees. Every business unit cannot run alone, financial problem and BUMDes development should be dealt with by all business units collectively. Gathering is the most efficacious way to establish close relationship between business units. Sometimes the employees of different business units and management hold futsal game competition together to bridge this relation, to grow sense of belonging, and consciousness among the employees, as the employees of not only business unit but also BUMDes.

Director of BUMDes' communication style is opened and participative, by which the employees may propose idea and thought, and see whether or not some job can be done jointly from many aspects. Communication between superior and subordinate beyond work hour is informal in nature, friendship and fluid relation. It emphasizes on Kampoeng Mataraman employees to make innovation, to explore innovation in bottom-up manner, and to build employees' loyalty in order to contribute to BUMDes. Similarly, BUMDes in Bleberan Village of Yogyakarta improves the professional managerial ability, particularly in the pillars of innovation, performance, and service quality (Fatimah, 2018). The Director does not restrict and compel the idea, builds togetherness, and improves sense of kinship with slogan lara siji lara kabeh, bahagia siji bahagia kabeh, mukti siji mukti kabeh (when the one is sick, everyone will feel the sickness; when the one is happy, everyone will be happy; and when the one is prosperous, everyone will be prosperous as well).

Director of BUMDes is aware of the importance of looking for and running business without subsidy and cannot rely on village, regency, and provincial governments for not cutting the employees' salary or wage and for the employees' housing. The director tells the employees to maintain their working rhythm and income target security, to enable the minimum income of business unit to potentially achieve BEP (Break Even Point), to give the employees the understanding that BUMDes is given target by village government within one year and how to achieve the target. It is confirmed with Schrodt (2002) in West and Turner (2013) stating that organizational culture involves emotional and psychological climate or atmosphere such as employees' work spirit, attitude, and productivity level. The pattern of relation between village government and villagers so far is still administrative in nature; therefore BUMDes extends public service to include service over public product and service.

Performance of Village Tourism Manager's Ritual in Managing BUMDes. The manager of Village Tourism facilitates participative planning to find Kampoeng Mataraman concept, followed with the activity of building the facilities in the attempt of introducing shelter, focusing on cloth, food, and shelter. How to build shelter or place including such facilities as building thereby apparently prioritizing Mataraman Java culture? After the shelter or facility has been constructed, try to run the program business, how to work on the program in the attempt of achieving local food sovereignty? How can the business be initiated and involve the people, particularly to make the vulnerable group sold out in the market? These questions are also answered by BUMDes in Semarang by involving high public participation in the implementation of BUMDes activities through business units belonging to BUMDes and community groups establishing partnership with BUMDes (Ihsan, 2018).

The manager gives briefing unlike a meeting but chatting together with employees about what to be sold, going back to traditional food, and type of food. The guests' evaluation on food is often made the material of discussion, chatting, and meeting considering the employees' limited experience and low education level. Manager visits the division employees in his leisure time to chat and to discuss with them concerning the employee's job. The manager uses a two-way communication style, emphasizing more on the assumption that everything should not come from the top manager, even suggestion or critique can come from bottom-up. Some employees who do not express their opinion 
bravely in WA group will see the manager directly to maintain friendship and brotherhood. Employees see each other to discuss and to tell their friends considered as wrong or less good and to find the solution to change behavior or anything that can break the brotherhood.

The topic of meeting held by BUMDes Panggungharjo pertains more to strategic matter, business development, and relation with outsiders. It is also conducted by BUMDes in Semarang, in which the administrator of BUMDes' accountability process is performed as the attempt of evaluating monthly/annual work and BUMDes' business development in the future (Safitri et al. 2016). Technical meeting is dealt with by unit head by holding small meeting with coordinator for field supervision that should be done everyday to be synchronized then with the employees and guests' complaint. Whatever the complaint conveyed, it should be considered as something very valuable. Employees learn to accept critique well as it is difficult to accept critique that sometimes hurts our ear and heart.

Kampoeng Mataraman business unit operates in tourism sector so that employees need training for serving the guests friendly and with smile (sumeh and semanak). Similarly, it is also performed by the management of BUMDes in Gunung Kidul Yogyakarta that improves its service quality and organization-managing ability (Anggraeni 2016). Socialization is conducted by allowing community group, FWP, farmer group, Karang Taruna (Youth organization), and RT to utilize the facilities available in Kampoeng Mataraman, and even BUMDes is ready to help when the community needs help, for example in the term of consumption.

Communication and interaction in BUMDes run fluidly and full of joke, morning chatting concerning job problem before going to work, during working, or in leisure time. Lurah, Director, Manager, and friends often chat with each other from the night to the dawn. The fluid circumstance can make the heart happy and the mind comfortable that in turn can build positive energy. Happy inner circumstance results in positive thinking, many ideas and thoughts emerging, so that anyone can do anything productively and comfortably.

Friendship relation makes the employees willing to sacrifice as a friend. Friendship is a local wisdom often heard and told to the guest in the philosophy wit kepel, soko kepel, kempel, kempal, kumpul (kepel tree meaning assembling to know, fill, complement, and help each other). Leadership is not by commanding but by inviting and participating in the work, just like the Lurah giving an example by driving the dump truck and cleaning toilet.

The employees of Kampoeng Mataraman live adjacently so that they can see each other in both workplace and at home. Politeness attitude builds on mutual respect; respecting each other in living within society will facilitate cooperation as coworkers. When some employees living adjacently are involved in a quarrel, it will make the workplace circumstance not conducive to cooperate maximally.

Politeness attitude in BUMDes can be divided into three categories: the character of employees coming from Panggungharjo village, that of those coming from outside village, and that of those coming from social service office. The character of employees coming from inside and outside Panggungharjo village is identical as they have shared idea to work and to earn living, while the character of social service employees has poor politeness because they have never lived on the street as wild people before. Management of BUMDes keeps including, learning, and motivating the employees to be acceptable to the community.

Entrepreneurial Behavior of BUMDes of Panggungharjo Village in Managing Village Enterprise. Basic entrepreneurship knowledge is innovation or new way of utilizing resource to create welfare (Drucker in Gani 2014). General innovation method used in BUMDes Panggungharjo is SCAMPER (Substitute Combine Adopt Modify Put into another use, Eliminate \& Reverse) method communicated more widely to the management concerning the formulation of innovation in different way. Calculated risking is more dominant, financial aspect risk analysis is also conducted, and business feasibility is viewed from market, HR and environment aspects. It is also accomplished by selling product other than food in Kampoeng Mataraman business unit like nandur pari (planting paddy), photobooth for selfie, planting flower, putting new building, renovating dump truck in the hangar and conveyor to unload rubbish in (Rubbish Processing Place), producing soap made of tamanu oil in attractive bottle packaging to raise the selling price. 
Table 1 - Ritual Performance of Village-owned Enterprise (BUMDes) of Panggungharjo Village

\begin{tabular}{|l|l|l|l|l|}
\hline No. & \multicolumn{1}{|c|}{$\begin{array}{c}\text { Performa } \\
\text { Ritual }\end{array}$} & $\begin{array}{l}\text { Lurah or Head of } \\
\text { Panggungharjo Village }\end{array}$ & \multicolumn{1}{|c|}{$\begin{array}{c}\text { Director of BUMDes } \\
\text { Panggung Lestari }\end{array}$} & Manager of Village Tourism \\
\hline 1. & $\begin{array}{l}\text { Personal } \\
\text { Ritual }\end{array}$ & $\begin{array}{l}\text { Giving informal briefing } \\
\text { about the heart/basic } \\
\text { value of BUMDes }\end{array}$ & $\begin{array}{l}\text { Growing loyalty and sense of } \\
\text { belonging among employees }\end{array}$ & $\begin{array}{l}\text { Visiting the employees in the } \\
\text { division to chat with them } \\
\text { about culinary matter }\end{array}$ \\
\hline 2. & Task Ritual & $\begin{array}{l}\text { Giving policy direction } \\
\text { and briefing to } \\
\text { BUMDes management }\end{array}$ & $\begin{array}{l}\text { Directing the business unit to } \\
\text { achieve the unachieved } \\
\text { target, coordinating, deciding } \\
\text { the policy in business unit, } \\
\text { maintaining work rhythm and } \\
\text { income target }\end{array}$ & $\begin{array}{l}\text { Facilitating participative } \\
\text { planning, building facilities, } \\
\text { running business, training } \\
\text { employees in catering on the } \\
\text { guest in Kampoeng } \\
\text { Mataraman business unit }\end{array}$ \\
\hline 4. & Social Ritual & $\begin{array}{l}\text { Giving role model } \\
\text { directly and making } \\
\text { discussion personally }\end{array}$ & $\begin{array}{l}\text { Holding gathering and futsal } \\
\text { game competition, building } \\
\text { togetherness and kinship } \\
\text { feeling }\end{array}$ & $\begin{array}{l}\text { Conducting socialization to } \\
\text { villager group or organization }\end{array}$ \\
\hline Ritual & $\begin{array}{l}\text { Initiating the } \\
\text { establishment of } \\
\text { BUMDes, holding } \\
\text { meeting with supervisor } \\
\text { and management }\end{array}$ & $\begin{array}{l}\text { Holding meeting with } \\
\text { managerial staff, internal } \\
\text { meeting in business unit, and } \\
\text { exploring employees' } \\
\text { innovation in bottom-up } \\
\text { manner }\end{array}$ & $\begin{array}{l}\text { Holding meeting to evaluate } \\
\text { menu, job-related problem, } \\
\text { and, employees, business } \\
\text { development and promotion }\end{array}$ \\
\hline
\end{tabular}

Table 2 - Result of Analysis on Entrepreneurial Behavior in BUMDes Panggung Lestari

\begin{tabular}{|c|c|c|}
\hline No & Category & Finding \\
\hline 1. & $\begin{array}{l}\text { Purposeful } \\
\text { Innovation }\end{array}$ & $\begin{array}{l}\text { SCAMPER (Substitute Combine Adapt Modify Put to another use Eliminate \& } \\
\text { Reverse) method, seeing differently and then combining it with SCAMPER. } \\
\text { Conducting risk analysis on financial aspect, business feasibility is viewed from } \\
\text { market, HR, and Environment aspects. } \\
\text { Innovation in the form of efficiency in RPS (Rubbish Processing House), by conducting } \\
\text { elevation to make the hangar in parallel with dump truck and unloading the rubbish } \\
\text { using conveyor } \\
\text { Producing any products from tamanu oil including soap packaged in attractive bottle to } \\
\text { raise its selling price. }\end{array}$ \\
\hline 2. & $\begin{array}{l}\text { Enterprise } \\
\text { Management }\end{array}$ & $\begin{array}{l}\text { The processing of tamanu oil to produce tamanu-seed bio energy } \\
\text { Recycling used cooking oil into factory engine fuel } \\
\text { Giving the villagers an education about environment-friendly farming to prevent them } \\
\text { from being dependent on chemical fertilizer in village tourism } \\
\text { BUMDes gives capital grant in the attempt of improving the potential SMEs. }\end{array}$ \\
\hline 3. & $\begin{array}{l}\text { Entrepreneurial } \\
\text { Strategy }\end{array}$ & $\begin{array}{l}\text { Local food without using msg or royco (chemical flavor enhancer) but using tempe } \\
\text { bosok. } \\
\text { Recovering Javanese past cultural circumstance by wearing Javanese clothing, using } \\
\text { Javanese cultural building, and recovering childhood memory in the village } \\
\text { Initiating business of selling food with local menu and cooking. Thus the food stall } \\
\text { business can impact farmers, and vegetable, rice, processed food sellers directly, such } \\
\text { as peyek and traditional snack. } \\
\text { Mastering local market with special tamanu oil product and special service of rubbish } \\
\text { service. Tamanu oil is the only one business type in Indonesia }\end{array}$ \\
\hline 4. & Constraint & $\begin{array}{l}\text { BUMDes has no tamanu basic material and no sufficient supply of used cooking oil } \\
\text { Not all SMEs have joined BUMDes } \\
\text { Has not gotten the ones to work on traditional market unit with an ability of building } \\
\text { entrepreneurial spirit among the people and involving lower-middle economic } \\
\text { entrepreneurs }\end{array}$ \\
\hline
\end{tabular}

Enterprise management in BUMDes prepares and arranges the management team through informal discussion in addition to the village government's prerogative right. It also asks BPD (Village Representative Council) for approving the change of SOTK (Organizational Structure and Work Mechanism). Advisor and supervisor give input to put the competent and experienced one for cadre building, to facilitate as teacher and learning media for the needing HR. The management anticipates financial need through saving post for salary and business development; receives and stores food, beverage, and skill resulting 
from villager SMEs' worker, and explores the need and gives capital grant in the attempt of improving potential SMEs.

The entrepreneurial strategies taken in Kampoeng Mataraman business unit is to start a business selling local food impacting directly on farmers, vegetable, rice, processed-food, and traditional snack sellers; to prioritize local knowledge without using msg or royco (chemical flavor enhancer) but using tempe bosok (putrid tempe); to recover Javanese past cultural circumstance by wearing Javanese traditional clothing and using Javanese-cultural building; to involve the people as the supplier of processed food and herbal (jamu) beverage; and to help both old and new SMEs that have not developed due to marketing difficulty.

Rubbish processing service is a social activity (benefit) while Kampoeng Mataraman business unit is a business-oriented activity that should be profit-oriented. BUMDes explores potency and creativity of Kampoeng Mataraman Village Tourism and potency of tamanu oil constituting the only one business type in Indonesia.

\section{CONCLUSION}

BUMDes' communication performance in managing a sustainable village enterprise can be seen from task ritual performance opening the participation space; personal ritual emphasizing on loyalty, role modeling, and information transparency and openness; social ritual including discretion to explore creativity, gathering, and exercise (sport) to establish intimacy, sense of belonging and kinship, communication in fluid circumstance; organizational ritual includes meeting to motivate and to maintain work rhythm and target security.

It can also be seen from the strategy used by means of building enterprise with local knowledge and skill including traditional cooking and medicine, Javanese culture and rural circumstance in village tourism, and recovering "Hamemayu Hayuning Bawono" value by giving environment-friendly education.

The author recommends the village government and BUMDes Panggungharjo to involve the employees who have not participated yet in the communication due to communication tool and age problem, to facilitate the need for rubbish transporting vehicle, for tamanu basic material not dependent on other villages, to deal with the work envy between the employees of Kampoeng Mataraman by strengthening the sense of belonging and organizational values, building the employees in order to have professionalism and not mixing personal problem with job, paying attention to the employees' excessive workload. The author also recommends the employees to learn accepting critique, to remove gap between street seller associations and to create wider entrepreneurship opportunity for the lower-middle economic villagers.

\section{REFERENCES}

1. Agunggunanto, E. Y., Fitrie, A., Edi, W. K., Darwanto. (2016). Pengembangan Desa Mandiri Melalui Pengelolaan Badan Usaha Milik Desa (BUMDes). Jurnal Dinamika Ekonomi and Bisnis 13(1): 67-81.

2. Anggraeni, M. R. R. S. (2016). Peranan Badan Usaha Milik Desa (BUMDes) Pada Kesejahteraan Masyarakat Pedesaan. Jurnal MODUS 28(2): 155-167.

3. Budiono, P. (2015). Implementasi Kebijakan Badan Usaha Milik Desa (Bumdes) Di Bojonegoro (Studi di Desa Ngringinrejo Kecamatan Kalitidu and Desa Kedungprimpen Kecamatan Kanor). Jurnal Politik Muda 4 (1): 116 -12.

4. Creswell, J. W. (2009). Research Design: Qualitative, Quantitative, and Mixed Methods Approaches. 3rd ed. Thousand Oaks, CA: SAGE Publications.

5. Das, D. C. (2014). Prospects and Challenges of Rural Entrepreneurship Development in NER-A Study. International Journal of Humanities \& Social Science Studies 1(3): 178182.

6. Denzin, N. K., Lincoln Y. S. (2017). The Sage Handbook of Qualitative Research, 4th ed. Thousand Oaks: SAGE Publications. 
7. Deshwal, S. (2015). Understanding The Youth For Embracing Rural Entrepreneurship as a Career. International Journal of Applied Research 1(13): 579-581.

8. Dewi, Y., Syahara, R., Meirinawati. (2013). Strategi Pembangunan Desa Dalam Mengentaskan Kemiskinan Desa Melalui BUMDes. Jurnal Publika 1(3): 1-15.

9. Eko, S. (2014). Desa Membangun Indonesia. Yogyakarta: Forum Pengembangan Pembaharuan Desa (FPPD).

10. Fatimah, P. L. R. (2018). Mengembangkan Kualitas Usaha Milik Desa (Q-BUMDES) untuk Melestarikan Ketahanan Ekonomi Masyarakat and Kesejahteraan Adaptif: Perancangan Sistem Kewirausahaan Desa dengan Menggunakan Model Tetrapreneur. Jurnal Studi Pemuda 7(2): 122-132.

11. Feher, A. (2014). Development Opportunities Of Rural Entrepreneurship By Participating In Training Projects. Research Journal of Agricultural Science 46(4): 45-51.

12. Firdaus, S. (2018). Fenomena Elite Capture Dalam Pengelolaan Badan Usaha Milik Desa (BUMDes): Studi kasus strategi bekerjanya kekuasaan elite dalam pengelolaan BUMDes Argosari, desa Pulosari, Kabupaten Pemalang. Jurnal Ilmu Politik 9(2): 20-37.

13. Gani, A. Y. A. (2014). Understanding Entrepreneurship: Memahami Secara Cerdas Makna Entrepreneusrship yang Sebenarnya. Malang: Universitas Brawijaya Press.

14. Guta, G., Vhudzi, G. \& Chazovachii, B. (2017). Sustainability of Rural Entrepreneurship as a Livelihood Strategy in Zaka District, Zimbabwe. Bangladesh e-Journal of Sociology 14(1): 70-80.

15. Hazarika, S. (2016). Skill Development for Rural Entrepreneurship: A study on State Institute of Rural Development (SIRD), Assam. International Journal of Research and Analytical Reviews 3(3): 61-66.

16. Hayyuna, R., Pratiwi, R. N., Mindarti, L. I. (2014). Strategi Manajemen Aset BUMDes Dalam Rangka Meningkatkan Pendapatan Desa (Studi pada BUMDES di Desa Sekapuk, Kecamatan Ujungpangkah, Kabupaten Gresik). Jurnal Administrasi Publik (JAP) 2(1): 15.

17. Ihsan, A. N. (2018). Analisis Pengelolaan Badan Usaha Milik Desa (BUMDes) Gerbang Lentera Sebagai Penggerak Desa Wisata Lerep. Journal of Politic and Government Studies 7(4): 1-12.

18. Kashani, S. J., Mesbah, A., \& Samira, M. (2015). Analysis of Barriers to Agricultural Entrepreneurship Development from the Perspective of Agricultural Entrepreneurs in Qazvin Province. Journal of Applied Environmental and Biological Sciences 5(12): 47-55.

19. Korsgaard, S. \& Müller, S. (2015). Rural entrepreneurship or entrepreneurship in the rural - between place and Space. International Journal of Entrepreneurial Behavior \& Research 21(1): 5-26.

20. Kushalakshi1, A. R. (2014). Rural Entrepreneurship: A Catalyst for Rural Development. International Journal of Science and Research (IJSR) 3(8): 51-54.

21. Kusuma, G. H. \& Purnamasari, N. (2016). BUMDES: Kewirausahaan Sosial yang Berkelanjutan. Baseline Research, Yayasan Penabulu.

22. Littlejohn, S. W., Karen A. F., John G. O. (2016). Theories of Human Communication, Eleventh Edition. Long Grove, Illinois: Waveland Press, Inc.

23. Murwadji, T., Rahardjo D. S., H. (2017). BUMDes Sebagai Badan Hukum Alternatif Dalam Pengembangan Perkoperasian Indonesia. ACTA DIURNAL Jurnal Hukum Kenotariatan and ke-PPAT-an 1(1): 1-18.

24. Munyanyiwa, T. \& Mutsau, M. (2015). Rural Entrepreneurship Challenges and Opportunities: A Case Study of Uzumba Rural Area in Zimbabwe. International Journal of Multidisciplinary Research Hub 2(7): 15-20.

25. Neuman, W. (2014). Social Research Methods: Qualitative and Quantitative Approaches. Pearson, Essex, UK.

26. Pacanowsky, M. E. \& Trujillo, N. O. (1982). Communication and Organizational Cultures. The Western Journal of Speech Communication. 46(2): 115-130.

27. Safitri, F. A., Susilowaty, E. \& Mahmudah, S. (2016). Tinjauan Yuridis Terhadap Pengelolaan and Pertanggungjawaban BUMDES Yang Belum Berbadan Hukum. Jurnal Diponegoro Law Review 5(2): 1-17. 
28. Singh, S. and Bhowmick, B. (2015). An Exploratory Study for Conceptualization of Rural Innovation in Indian Context. Journal of Procedia - Social and Behavioral Sciences 207: $807-815$.

29. Taghibeygi, M., Sharafi, L. \& Khosravipour, B. (2015). Identifying factors influencing the development of rural entrepreneurship from the perspective of farmers of West Islamabad country. Research Journal of Fisheries and Hydrobiology 10(10): 161-168.

30. Venkateswarlu, P. \& Ravindra, P.S. (2015). An Empirical Study on Problem and Prospects of Rural Entrepreneurs with Special Reference to Visakhapatnam District. International Journal of Management and Commerce Innovations 2(2): 458-467.

31. West, R. \& Turner, L. H. (2013). Introducing Communication Theory: Analysis and Application. 5th Edition. New York City: McGraw-Hill Education.

32. Yadav, V. \& Goyal, P. (2015). User innovation and entrepreneurship: case studies from rural India. Journal of Innovation and Entrepreneurship 4(5): 1-20. 